\title{
Flood risk consideration: a new paradigm? Urban examples in the middle valley of the Loire River (France)
}

\author{
J. L. Yengué ${ }^{1,4}$, M. Amalric ${ }^{1,4}$, D. Andrieu ${ }^{1,3}$, M. Fournier ${ }^{1,4}$, \\ J. Serrano ${ }^{1,4}$, S. Servain ${ }^{2,4}$ \& L. Verdelli ${ }^{1,4,5}$ \\ ${ }^{1}$ University François Rabelais of Tours, France \\ ${ }^{2}$ National School of Nature and Landscape of Blois, France \\ ${ }^{3}$ UMS Maison des Sciences de la Ville CNRS 1835, France \\ ${ }^{4}$ UMR CITERES CNRS 617, 33 allée Ferdinand de Lesseps, BP 60449, \\ 37204 Tours Cedex 3, France \\ ${ }^{5}$ Centro de Estudos Arqueológicos das Universidades de Coimbrae, \\ Portugal
}

\begin{abstract}
Flood plains experience a continuous stress between the prevention of natural risks and the need of space for new activities. Mankind is increasing its occupation of flood plains in spite of recurrent floods, following a certain aptitude to forget risk. This paper analyzes this conflicting situation, especially in the middle Loire Valley. The aim is to understand which factors have oriented the urban sprawl into the flood plains, through an analysis of the evolution of settlements by GIS, by the study of planning documents and by an historical analysis of flood protection orientations. The study shows that under the weight of a reinforced legal arsenal and some other pressures, the districts have begun to give up this unlimited and irrational urbanization. New strategies are appearing. They are split between the intent to give more space to the river and the intent to invent an urban planning design that is more compatible with flooding. This contribution theorizes that a new paradigm is emerging, combining geographical localization and mental representations of risk.
\end{abstract}

Keywords: flood plains, Loire valley, risk, urbanization. 


\section{Introduction}

Flood plains are dangerous. When the river overflows, human activities and lives can be dramatically damaged. Flood plains topography is often flat; accordingly inner-cities are often situated there. So flood plains are very much coveted although risky spaces. Here is a continuous stress between the prevention of natural risks and the need of space for new activities. Through an analysis of the evolution of settlements by GIS, by the study of planning documents and by an historical analysis of flood protection orientations, we are going to characterize the balance between urban development and flood management in the middle Loire Valley. We will show the shift from the unlimited urban sprawl during the last decades (2) to its end with the recognition of the dangerousness of the Loire River by official protection documents (3). This forces districts to adapt their development according to the flood risks (4). But the history of flood protection in the middle Loire Valley shows that what is appearing to change (the domination connection with the river) might only be a cyclical process (5).

\section{Proving man's superiority on natural elements}

Before the industrial age, in France, many cities used to be set up far away from the flood risks or, at least, just out of reach of flooding (up on the hills). Flood defences were built to protect agricultural lands from flooding and help navigation, but they did not prevent the main flooding events (Barraqué and Gressent[1]). As soon as the industrial period began, and even more so after the First World War, urbanisation widely stretched into flood plains. Dikes, dams, hydraulic works were progressively reinforced along French rivers to prevent main floods (Scarwell and Laganier [2]). French rivers were no longer regarded as just waterways but also as major water resources that had to be managed (times of the "houille blanche" i.e. hydroelectric power).

In the middle of the Loire Valley, the city of Tours is an outstanding example (Dutour et al. [3]). The old city of Tours settled on the bank of the river, within its bed, on two mounds, out of the reach of floods (Dion [4]). Since then, the city never stopped developing, mainly in the bed of the river, i.e. in flood prone areas, whereas other cities along the Loire river mostly spread on the higher sides of the river.

Between the First and the Second World War, the phenomenon of urban spreading slowed down everywhere in France. After WWII, there came a period of high economic growth in France, called the "30 glorieuses" (The Glorious Thirty years). The demographic growth and the important reconstruction activity due to the bombings led to the enhancement of the flood defences. Major works were achieved along French rivers, such as new dams, higher dikes and levees, larger embankments, diggings and straightenings of rivers. These works participated in the so-called "total flood risk control illusion" ( "l'illusion de la maîtrise totale des inondations") (Girardin [5]). The absence of flood events during these 30 years reinforced this feeling. Flood defence works were targeting two different goals: (i) to control the water resources for irrigation, industries and the urban areas; (ii) to 
develop activities and housing in the floodplains. Theses two bounded goals were the consequence of a high demand, at that time, for housing, industries and for transport and telecommunication infrastructures. Therefore, building activities and civil engineering were fully expanding. In 1958, the French State got involved in a real housing policy and became in charge of the building of 4 million homes. The days of housing estates began. Because it was public funded, three main goals were underlined: "emergency", building up very quickly; "mass" building up a lot; "bargain", building up cheaply (Simon [6]).

In Tours, public town planning started with small-size building works but it grew quickly to a huge extent. Council housing and private homes were both concerned. This housing program took place in the districts of the city already built, where room was available, in a way, thanks to the bombings. However, most of these constructions needed a wide spare space to be set up. The flood plains, whose topography was flat and that were close enough to the city centre, were the first places where new construction took place.

During the "Glorious Thirty Years", flood probability never happened to be a concern in choosing the place to be built up. In 1960, the lack of accommodation was a serious problem in Tours and the plain of the Cher River was the only place available to expand. Yet, the place was overflowed every year, due to the rise of the stream and to infiltrations from the subsoil. The urbanisation of the Cher's bed became one of the most important urban planning projects Tours had ever issued (Lussault [7]). The "Bank of the Cher River" project consisted in a massive $7 \mathrm{~km}$ long straightening of the stream; it converted a semi-natural area into a totally artificial canal (Bomer [8]). The bed-width was doubled, meanders were deleted, very high and strong dikes were built, an island was built and very wide embankments were filled with rubble, and a huge number of homes were built (around 6522 flats). Those works are said to be the biggest building site in Europe during the 1960's. In the middle of the 1970's, the economic recession suddenly slowed the building activities and delayed the $4^{\text {th }}$ and last step of the urban project, the Gloriette plain land planning ("la plaine de la Gloriette") in the western part of the Cher River. Nevertheless, the whole building site contains more than 14000 homes, in the flood plain of Tours, between the Loire and the Cher Rivers.

At the beginning of the 1980's, environment awareness arose and many naturalist associations and NGO's began to organise and to militate against the project. A powerful lobby emerged, that went with a new period: technical management was not considered as effective as natural process. Finally, in 1994, the project stopped short because of the implementation of the law prohibiting the embankment and the construction of any new building in floodplains. The project remains half built: just a small part of the plain, known as the borough of "les deux lions", where embankments were already made, has been achieved.

\section{A new approach in the field of flood management with the development of "non structural" measures}

The behaviour towards flood risk and its perception started to change radically after several events. First of all, on the international level, the Rio Summit 
emphasized the concept of sustainable development while many disastrous floodings occurred round the world. Later on, on the French national scale, after several decades without any major flood events occurring, dramatic floods took place between the beginning of the 1980's and 1994. It quickly appeared that no matter the protection works that may be set up, the risk is never nil. Those events led to a quick evolution from an emphasis laid on protection works to face the flood risk to a new flood management policy, mainly focusing on the issue of flood prevention. Within the frame of such a new strategy, the ambition was to focus not only on the hazards but also on the issues at stake.

Therefore, in 1994, public policies on natural hazards prevention got reinforced, thanks to new regulations and to an increase of funding. Before this date, different regulations existed without being very much effective, mostly because they were difficult to implement. The oldest management plan concerned the map of flood plains, 1935 (plans de surfaces submersibles PSS); then, in the 1950's, the "urban planning Code" (code de l'urbanisme) (article R111-2) restricted urban sprawl. Its action was reinforced in 1995, with a new article (R111-3) defining risk limits as a security zone (perimeters of risk, périmètres de risque). At the same time, an action plan on risk exposure was created (plan d'exposition au risque) and the General Interest Project (plan d'intérêt général PIG) was launched. The main concern was based on nonstructural measures (i.e. restricting the settlement of vulnerable industrial activities, allowing the flood expansion into spared spaces, improving the alert system by modernizing the watch flood system). Pottier (Pottier [9]) shows that Anglo-Saxons make a difference between (i) structural measures : measures that are taken to protect the floodplains against floods; they consist mainly in hydraulic works (dams, dikes, spillways) (ii) non-structural measures : measures that consist in modifying land uses or activities ; land use planning, construction rules, rescue measures are some other examples of "non-structural" measures.

Thanks to a juridical arsenal and to massive funding, never seen before in France, these measures came true. What did the measures consist in?

First of all, the modernisation of the law on the flood risk gave birth to the PPRi (Plan de Prévention des Risques Naturels d'inondation, Natural Risk Prevention action Plan, i stands for flooding) which cancelled the former procedures. The PPRi is simpler thanks to its definition of limits of flood-prone areas and their specific planning regulations which are not submitted to expensive and complex feasibility studies anymore. At the same time, different kinds of risks were being taken into account and the action plans were easy to modify if necessary. Finally, the PPRi is applying not only on urban zones but also on rural and periurban zones, it prevents urban spread and protects the expansion of flood hazard zones (zone d'expansion des crues). Concurrently, from the funding point of view, important means were being released by the French State. Before 1994, 15MF (about 2m Euros) were used for the cartography of risk, in 1994, funding was raised to 40MF (almost 6m Euros) and nowadays, more than $60 \mathrm{MF}$ (10m Euros) are used to improve the knowledge of the risk and of its limits and to improve the quality of communication strategies upon the risk. This led to the realisation of the Flood-prone areas Atlases (Atlas 
des zones inondables), everywhere in France, based on the highest water level ever known (limite des plus hautes eaux connues). These atlases improve the knowledge on floods, how they work, where they expand, and map them, thus helping the PPRi with deciding on what urbanisation limits should be. The cartography of risk is also a way of involving the stakeholders: they have to be conscious of and responsible for the flood risk. Even if atlases are not part of the juridical arsenal, they help to get more involvement from the public decision makers: precedent shows that the "case of absolute necessity" is less and less taken into account when catastrophic floods happen. Another important regulation relies on the 1995 Law concerning the right to expropriate. As long as a place is considered to be highly exposed to natural hazards, people living there can be expropriated and can receive compensation, if the French State evaluates that the total cost of the prevention is higher than the value of the goods. The funding for this measure comes from the "natural disaster additional premium", linked to the Insurances plans (15m euros).

The implementation of the PPRi quickly revealed that large urban areas are at high risk, even though they are protected with dikes. While the implementation of the PPRi regulation is still continuing, two main issues have been highlighted: - to protect expansion of flood hazards zones from urban sprawl, allowing the flood to spread. The natural functions of these zones are to lower the flood level and to limit the river vigour,

- to forbid any new embankments or new dikes to be built unless they are meant to protect previously built-up areas.

\section{How are PPRi constraints taken into account in planning documents and projects?}

As more and more PPRi's are being launched and implemented, urbanisation is facing a halt in flood-prone areas. Hence, institutional stakeholders try to find new strategies to tackle both issues of flood protection and local development in their districts or territories. Today, one major trend is the emphasis laid on those flood-prone areas as important and valuable assets in terms of quality of life for the districts where they are located (open and green space, landscape, natural and cultural heritage...). This trend is even reinforced on the Loire River, as the valley is inscribed on the UNESCO World Heritage list (within the category of the living cultural landscapes).

Political interests developed by institutional stakeholders for those areas often clearly appear in the planning documents (Verdelli et al. [10]). They can be divided into 3 groups:

1. In the districts located on both hills and floodplains, urbanisation has now stopped in the flood-prone areas; planning documents confirm that position. The districts stress on the amenities (natural or cultural heritage) of flood-prone areas and plan urbanisation on the hills, where lands used to be traditionally dedicated to agriculture (it creates a new pressure on this activity). All those districts show their will to strengthen their cultural dynamism and reaffirm their links with the Loire River (they try to preserve the image of a wild river) but also to develop 
their potentialities for tourism and leisure activities. They lay the emphasis on the uniqueness of their identity and the architectural (with the massive use of slate and freestone, the maintenance of cliff dwellings) but also on the natural heritage (hills, vineyards and green belts) of the Loire Valley. If we consider the case of Tours, the last step towards urbanisation on the Cher floodplain (Gloriette plain) is different from what used to be done in the last decades. The current project is a mix between a city and a leisure park.

2. Some rural districts are completely located in flood-prone areas. In this case, urbanisation also stopped and now those districts tend to focus on new activities such as the development of cultural events for instance. The most striking example is the one of the district of Bréhémont, about 50 kilometres away downstream from Tours. This district exploits a wide variety of tourist assets enhancing the natural and cultural heritage of the place. Regular events introduce the old traditional activities of the place: trips on the Loire on typical boats from the region, organisation of the "Hemp festival", during which the elders organize exhibitions of their former activities (hemp culture or traditional navigation). In order to set up such events, the traditional port and its embankments and quays have been restored. The conservation and restoration of the built environment is also a major concern; in Bréhémont, it has led to the reconstruction of the whole traditional urban landscape. Eventually, thanks to some large marketing events, such as the opening of the European Rivers Biking Road that follows the Loire River on the "Loire à vélo" (Biking by the Loire) and the indirect fame gained from the UNESCO inscription, the district of Bréhémont gets revenues from tourism. In order to build new housing even though new constructions are not allowed, old traditional barns will be restored with special care on the fact that they are located in flood-prone areas; hence, they will be adapted to floods.

3. The last case is the one of the outskirts whose territory is completely located in flood-prone areas. In their case, tourism is not a good strategy to find new revenues as they lack typical landscapes and present a very plain urban landscape and pattern. Hence, they are excluded from the tourist circuits (if we omit the green areas they can offer to the inhabitants of the urban area close by). As a consequence, they tend to adopt a mixed position, as they try to maintain their demographic and economical development but also have to respect the constraints of the PPRi. In practice, they tend:

- to preserve the agricultural activity which used to be and is still remaining a strong characteristic of those areas. They try to make it appear as added value for their territory, especially among young couples that wish to live in a "natural" environment. Planning documents do lay the emphasis on that aspect, even though it remains difficult for the districts to reach that goal. Indeed, their ambitions and resolutions have very little influence on the protection of those open lands as it mainly depends on the wealth of the local farmers and private owners.

- to densify and extend their built-up environment, within the rules given by the PPRi (densification is possible in some flood-prone areas that are already built, especially if the level of risk is low). Thus, they try to optimise the land use 
so that the plain urban sprawl might become an urban continuum. New constructions have to conform to very strict rules taking into account the flooding issue (wiring and gas diagram are fitted in the ceilings, houses must be only two-storeyed with their living rooms elevated to be kept dry and their windows accessible as a potential exit). Since the mid-1990's, those areas are the only flood-prone areas where urbanisation has kept developing, for instance in the district of La Riche, downstream from Tours. This district is still considering its development through the densification of its urban pattern and its residual spaces; the town council considers that there is still a possibility for about 7 hectares to be built.

Taking into account those different strategies, it appears that one major consequence of the implementation of the PPRi regulation is the maintenance or the new development, sometimes quite unintentional, of agriculture on the city outskirts. Still, there is no guarantee that this activity will remain perennial, as it often faces difficulties. Now, it seems that some solutions can be found by favouring on the one hand organic or vegetable growing that can be sold on local markets and on the other hand the exploitation of the land for bio fuel (bio carburant).

If we consider the new trends, it appears that:

- The districts tend to take into account the fact that they are located in floodprone areas (while it used to be something completely denied)

- The districts adapt urbanisation and the location of their activities, as it used to be in former times.

Considering this last point, the PPRi and its so-called innovation might only be a "flashback" being part of a cyclical process.

\section{5 "More room for the river": a new strategy on the Loire River?}

A "new" strategy has been developing for the last few years and starts to be confirmed: the will to give more space for the river and prepare some areas for that possibility. In a way, it can be considered as a step backward but also as a resolution to correct "former mistakes".

It is the case of Blois for instance, where a project is already very much advanced. While the heart of the city of Blois is located on the right-hand bank of the Loire, an old discharge channel is located on the left bank: it is referred to as the spillway of la Bouillie. It was built in the $17^{\text {th }}$ century and this flood defence was supposed to protect the city of Blois by letting the water flows run trough the plain of the left-hand side of the river. It was flooded during all the major floods until 1907 (last major flood on the Loire River). Since that time, there has been no new major flood and memories of the usefulness of that hydraulic work slowly disappeared, allowing some houses to settle in the discharge channel. At the beginning of the 2000's, there were 135 houses and 14 firms (as well as some sport infrastructures) built directly in the discharge channel. After the elaboration of the local PPRi in 1999, a project was launched by the State administration (in cooperation with the district) to restore the 
spillway so that it could be used again in case of flood. In order to prevent damages and accidents, the ambition was to restore it as an open land. As a consequence, all the houses had to be bought and destroyed. The process is still going on, even though it faces strong local oppositions widely echoed by the national and local media.

In a way, this new approach can appear as a step backward or, more positively, as a "flashback", i.e. a comeback towards traditional habits and adaptations to the reality of flood-prone areas.

Contrary to the appearances and to the stakeholders' words, the strategy of giving more space for the river flooding is not something new on the Loire River. It had already been enhanced in the $19^{\text {th }}$ century and even much earlier in the past. Therefore, it seems that the whole history of flood management on the Loire River has been continuously swinging from the ambition of constraining the river to the recognition that there was a need to give it more space.

If we reconsider history, it appears that many projects were launched several times between the $17^{\text {th }}$ and the $19^{\text {th }}$ century along the Loire River to lower dikes in some specific areas. This strategy always emerged after major flood events that completely destroyed the cities and the valley.

In 1629, after 2 major floods (1608 and 1628), King Louis XIII considered the impossibility of containing the floods on the Loire River with continuous dikes. It was decided that 6 spillways would be built where it would be the most convenient and the least damageable (from Ouzouer to Saumur). This project was also influenced by the success of a very new system: the system built in Blois in 1618 (the one we mentioned above: the discharge channel of la Bouillie). However, strong oppositions arose from the cities on the Loire and none of the 6 projects was built. On the opposite, new building works were quickly realized by the successors of Louis XIII to raise the dikes (Colbert's works, 1668).

Then, in 1711, once more after 4 major floods (1707, 1709, 1710 and 1711), a new project to create spillways within the protection system was suggested (in parallel, some dikes were raised) and enlarged). Some spillways were built between Gien and Tours. But they were completely destroyed during the next major flood. As the engineers were not all convinced of their relevancy, the decision was made to keep the old spillway built in Blois as well as another spillway located close to Gien (also built in the beginning of the $17^{\text {th }}$ century). But all the others (they might have been about 6 or 7) were destroyed and the dikes were heightened instead.

Eventually, in 1867, once again after 3 major floods $(1846,1856,1866)$, a new project was launched by the engineers of the "Ponts et Chaussées" (the State civil engineers) on the Loire River, to create 20 spillways on the dikes of the river. This program was planned on the scale of the whole river but the projects of spillways were all located between Nevers and Saumur.

The system planned in the $19^{\text {th }}$ century was different from the one planned in the two former projects. In the $17^{\text {th }}$ and $18^{\text {th }}$ centuries, the weir of the spillways was quite low (about $4 \mathrm{~m}$ high) and the area located behind the spillway was bound to be flooded quite early when the flood occrred. In the $19^{\text {th }}$ century, the weirs of the 
spillways were fixed much higher (first, at about $4 \mathrm{~m}$ or $4,50 \mathrm{~m}$ and then at about $5,50 \mathrm{~m}+1 \mathrm{~m}$ or $1,50 \mathrm{~m}$ for the bank). With this strategy, the "Ponts et Chaussées" engineers wanted to let the water flow into the floodplain as late as possible and decrease the level of water within the riverbed as much as possible. As a matter of fact, the spillway was planned to be flooded at the extreme limit before a breach would occur in the dike. In the $19^{\text {th }}$ century, only 7 spillways were built.

Today, the State administration considers restoring them and continues the work that started in the $19^{\text {th }}$ century. Still, its approach is theoretically a little bit different from what it used to be: the new spillways are conceived to protect the area where there are located (ex: the valley in Nevers is an area with major issues: therefore a spillway should be built in this part of the valley). Hence, the protection is designed locally. In the $19^{\text {th }}$ century, the system of spillways was addressed on the scale of the whole "Middle Loire Valley" (from Nevers to Saumur). There were two ambitions:

- to lower the general water level of the watercourse

- to protect the issues at stake in the urban areas

In the mind of the State civil engineers, the rural areas were also protected, even though they were the ones to be flooded, because the water flows would at least be controlled. But contrary to what is planned today, the areas where the issues were the most important were completely protected by dikes (ex.: around Tours, there was no spillway planned) while several spillways were planned in rural areas where the floodplain is wide.

Therefore, even though some similarities can appear between past and present, the strategies of implementation seem to be quite different.

\section{Conclusion}

Planning policies in flood-prone areas have evolved within the last past centuries. Buildings in flood plains, especially urban constructions such as housing estates or industrial activities, were alternately sprawling wildly, planned by local or national authorities, restricted to some limited areas or strictly stopped by laws and regulations.

In France, the reinforcement of the juridical arsenal increased in the middle of the 1990's. The implementation of the PPRi, helped by the mapping of the floodprone areas (Atlases), led to new urbanization trends in the Loire Valley. Depending on their situation in the valley, districts conceived different strategies to cope with the PPRi constraints. Local authorities adopted three different positions on the management of urban sprawl in flood plains. The first one is to stop buildings in flood-prone areas and to exploit the natural and cultural heritage linked to the river. The second position consists in keeping building in flood-prone areas, with a higher flood-proof design and a higher urban density. The third alternative lays on the "more room for the river" strategy; it relies on a duplicated use of the valley: either green spaces and agriculture lands or expansion flood hazard zones. This implies a limited value of the activities or infrastructures settled in the flood plain.

The French case of the Loire River shows that the paradigm concerning the urbanization of floodplains has changed from the conception of omnipotence 
based on technical skills to a larger role given to the natural dynamics. Nevertheless, it is rather a reference to an old paradigm than a new position, as the example of the spillways shows. What presented as an innovation is more precisely a flashback to former strategies. The paradigm revives with original formal implementations, but the philosophy only swings from a position on the flood management to another.

This cyclical process leads to two new questions:

- Is the next step concerning flood management in the Loire valley a return to more building-up in flood-prone areas and to more negotiations with the PPRi?

- Is the Loire River bound to be the field of new aberrations in terms of floodplains management within the next decades?

\section{References}

[1] Barraqué B., Gressent P, La politique de Prévention du Risque d'Inondation en France et en Angleterre: de l'action publique normative à la gestion intégrée, Rapport final, Ministère de l'Écologie et du Développement Durable et UMR-CNRS 8134, Université Paris XII, 122 p. 2004

[2] Scarwell H-J, Laganier R, Risque d'inondation et aménagement durable des territoires, Septentrion Presses Universitaires, 239 p. 2004

[3] Dutour A., Garnier Ph., Genin A., Servain-Courant S., Développement de la ville de Tours et zone inondable: le cas du Val du Cher, Actes du Colloque Hydrosystème, paysages et territoires, Lille 6-8 September 2001

[4] Dion R, Histoire des levées de la Loire, Paris, 312 p. 1961

[5] Girardin F., Urbanisation et inondations: de l'opposition à la réconciliation, Actes du Colloque Hydrosystème, paysages et territoires, Lille 6-8 September 2001

[6] Simon J, L'extension spatiale de l'agglomération tourangelle; les difficultés d'un aménagement global, Mémoire de Maîtrise de Géographie, Tours. 1977

[7] Lussault M, Tours: images de la ville et politique urbaine, Ed. MSV collection Sciences de la Ville, n³, 415 p. 1993

[8] Bomer B., L'évolution des lits de la Loire et du Cher dans l'agglomération tourangelle, Cahiers de la Loire Moyenne, $\mathrm{n}^{\circ} 10-11$, pp. 97-103. 1982

[9] Pottier N., L'utilisation des outils juridiques de prévention des risques d'inondation: évaluation des effets sur l'homme et l'occupation des sols dans les plaines alluviales (application à la Saône et à la Marne), Thèse en Sciences et Techniques de l'Environnement, Ecole Nationale des Ponts et Chaussées, 436 p. + annexes. 1998

[10] Verdelli, L., Servain-Courant S., Andrieu, D., Corridor fluvial ligérien, observatoire privilégié des interactions nature-société, le cas de l'agglomération de Tours, Actes Colloque international interaction nature société: Analyses et modèles La Baule du 3 au 6 May 2006 (CD-Rom) 